\title{
DETERMINATION OF THE WATER QUALITY INDEX (WQI) OF A FRESH WATER STREAM (Mini-Whuo) ELIOZU, RIVERS STATE, NIGERIA.
}

\author{
I.R. ALLISON ${ }^{1}$, C.C. OBUNWO ${ }^{1}$, G.A. COOKEY ${ }^{1}$, and O.S. BULL ${ }^{1}$. \\ ${ }^{1}$ Department of Chemistry, Rivers State University, Nkpolu-Oroworukwo, Rivers State Port Harcourt \\ Nigeria. \\ *Corresponding Author: Email: irimaa@yahoo.com \\ Received 28 June 2020; accepted 12 July 2020, published online 28 August 2020
}

\begin{abstract}
In order to assess the potability and agricultural application of Mini-Whuo stream in Eliozu Port Harcourt, Rivers State, Nigeria; the physicochemical properties, heavy metal levels ( $\mathrm{Fe}, \mathrm{Cr}, \mathrm{Cd}, \mathrm{Pb} \& \mathrm{Ni}$ ) and microbiological load of water were evaluated. Five stations were established and sampling made for a period of six months (May-October 2019). Various water samples were collected for the analysis of physicochemical properties, heavy metal and microbiological levels, using titrimetric, spectrophotometric and microbiological methods respectively. Results obtained from the analyses showed that, temperature ranged between $\left(28.7 \pm 0.7-30.9 \pm 1.9^{\circ} \mathrm{C}\right), \mathrm{pH}(6.4 \pm 0.0-6.7 \pm 0.3)$, electrical conductivity $(82 \pm 20-172.0 \pm 14$ $\mu \mathrm{S} / \mathrm{cm})$, total dissolved solids $(41 \pm 1-86.5 \pm 71.1 \mathrm{mg} / \mathrm{l})$, turbidity $(8.1 \pm 1.6-18.1 \pm 2.8 \mathrm{NTU})$, chloride $(5.60 \pm 1.63-7.76 \pm 0.96 \mathrm{mg} / \mathrm{l})$. Levels of heavy metals analyzed for water were below detection limit of $0.01 \mathrm{mg} / \mathrm{l}$, except for $\mathrm{Fe}$ which ranged between $(3 \pm 1-4.6 \pm 0.8 \mathrm{mg} / \mathrm{l})$. Microbiological study of water showed that the water had $\left(2.6 \pm 0.5-6.4 \pm 0.6 \times 10^{3} \mathrm{cfu} / \mathrm{MLN}\right)$ count of total heterotrophic bacteria, $(44.3 \pm 9$ $\left.323.8 \pm 44 \mathrm{MPN} / 100 \mathrm{ml}^{-1}\right)$ count of total coliform bacteria count and $\left(4.3 \pm 2.7-59.5 \pm 16.9 \mathrm{MPN} / 100 \mathrm{ml}^{-1}\right)$ faecal coliform bacteria count. From the result of analyses it was observed that iron, dissolved oxygen, electrical conductivity, total dissolved solids, and the microbiological load of the water were high when compared with WHO standards, and this may be attributed to the disposal of wastes such as, human and animal wastes into the water body. Water quality index (WQI) method according to the weighted arithmetic WQI, where (WQI $<50=$ excellent water quality), $(50>\mathrm{WQI}<100=$ good water quality), $(100>\mathrm{WQI}<200=$ poor water quality), $(200>\mathrm{WQI}<300=$ very poor water quality), and (WQI > 300 $=$ unfit for drinking). Based on the WQI calculated for the Mini-Whuo stream 1156, the stream is not suitable for domestic use.
\end{abstract}

Key words: Water Quality Index, Mini-Whuo, Rivers State, Nigeria, Freshwater, Physicochemical Properties, Heavy Metal Levels, Microbiological Load, Atomic Absorption Spectrophotometer.

\section{INTRODUCTION}

The importance of water to the well-being of man-kind, plants and animals cannot be over emphasized [1,2]. Man-kind can stay without food for a longer time than without water [3,4], Water is naturally classified as fresh, brackish and marine water [5]. Rivers State is a state crisscrossed with rivers and streams, and the inhabitants have access to these water bodies [7].

Rivers transport metals partly dissolved and partly adsorbed on suspended materials. Water pollution heightens the threshold of heavy metals and this usually poses serious threat to human health, natural and semi-natural ecosystems [8]. Non-essential heavy metals such as lead $(\mathrm{Pb})$ and cadmium $(\mathrm{Cd})$ are emitted and globally distributed mainly through anthropogenic activities such as fossil fuel exploration and consumption, the use of inorganic fertilizer for agriculture and industrial constructions. The effects of these heavy metals on animals have been clearly established. For example, exposures to lead poisoning in humans and animals have been a concern for more than a century [10]. Cadmium has been described as one of the most dangerous trace elements in food and the environment, not only for its high toxicity but also its high persistence in the 
environment [9]. Although other heavy metals including zinc ( $\mathrm{Zn})$ and iron $(\mathrm{Fe})$ are essentially required for supporting biological processes, their environmental concentration beyond an acceptable limit constitutes serious toxicological problems [10].

The environment has continued to suffer from pollution due to increased urbanization and industrialization [11]. On the other hand natural resources such as land have remained constant leading to overcrowding of population around towns and cities. The biggest challenge of this effect is waste disposal. Domestic and industrial wastes are being disposed-off surface water bodies like rivers and dams on a daily basis. This has led to contamination of surface water bodies, especially from heavy metals [12].

There is an increasing concern about the deteriorating state of surface water bodies in Port Harcourt, Southern Nigeria as it relates to heavy metal pollution. Anthropogenic activities along major rivers are common and widespread. Mining activities, agricultural activities and industrial and domestic waste disposal along Mini-Whuo stream could be some sources of heavy metal contamination.

Water quality index (QWI) is one of the most reliable tools to communicate information on the quality of water to concerned citizens, researchers, assessors and policy makers $[13,15]$. Water quality index provides a comprehensive picture of the quality of surface/ground water for most domestic uses [13].

The use of WQI in determining the particular water body have increased tremendously since the initial WQI development by Nwankwoala and Ogbonna [15], as well as improved version by Ademiluyi and Odugbesan [16]. This is due to the fact that WQI provide a number, simple enough for the public to assimilate. This implies that the overall water quality at a particular area if tested with the specified or selected water quality parameter should be able to give an overall view of its quality [13]. However, the weighted arithmetic index method (WAWQIM) is commonly used among assessors in developing countries in which Nigeria is one [8]. In this study, however, the water quality index was used as a tool to assess the impact of some activities such as metal working, abattoir, indiscriminate dumping of home and market wastes and automobile works around the MiniWhuo stream.

\section{STUDY AREA}

A number of activities take place along the study area as shown on Figure 1. Station 1 is located between longitude N04.88086 and latitude E007.01261 ${ }^{\circ}$.The water body in station 1 is the upmost part of the stream. Activities such as production of bricks and sale of metal parts are carried out within this station. Station 2 is located between, longitude $\mathrm{N} 04.85933^{\circ}$ and latitude E007.02537 ${ }^{\circ}$, and building activities are carried out in this area. Station 3 is located between longitude N04.86361 ${ }^{\circ}$ and latitude E007.01972 $2^{\circ}$.Activities carried out in that area are welding works, production of bricks, garden and abattoir. Station 4 is a culvert. It is located between longitude N04.85939 ${ }^{\circ}$ and latitude E007.02387 and major activities at station 4 are the production of planks and the parking of waste vehicles. Station 5 is the downstream of all stations, it has a water fall, activities carried out are fishing, repair and washing of cars, market, and abattoir. It is located between longitude $\mathrm{N} 04.86736^{\circ}$ and E007.01655 . Generally similar activities are carried out in all stations along the stream. 


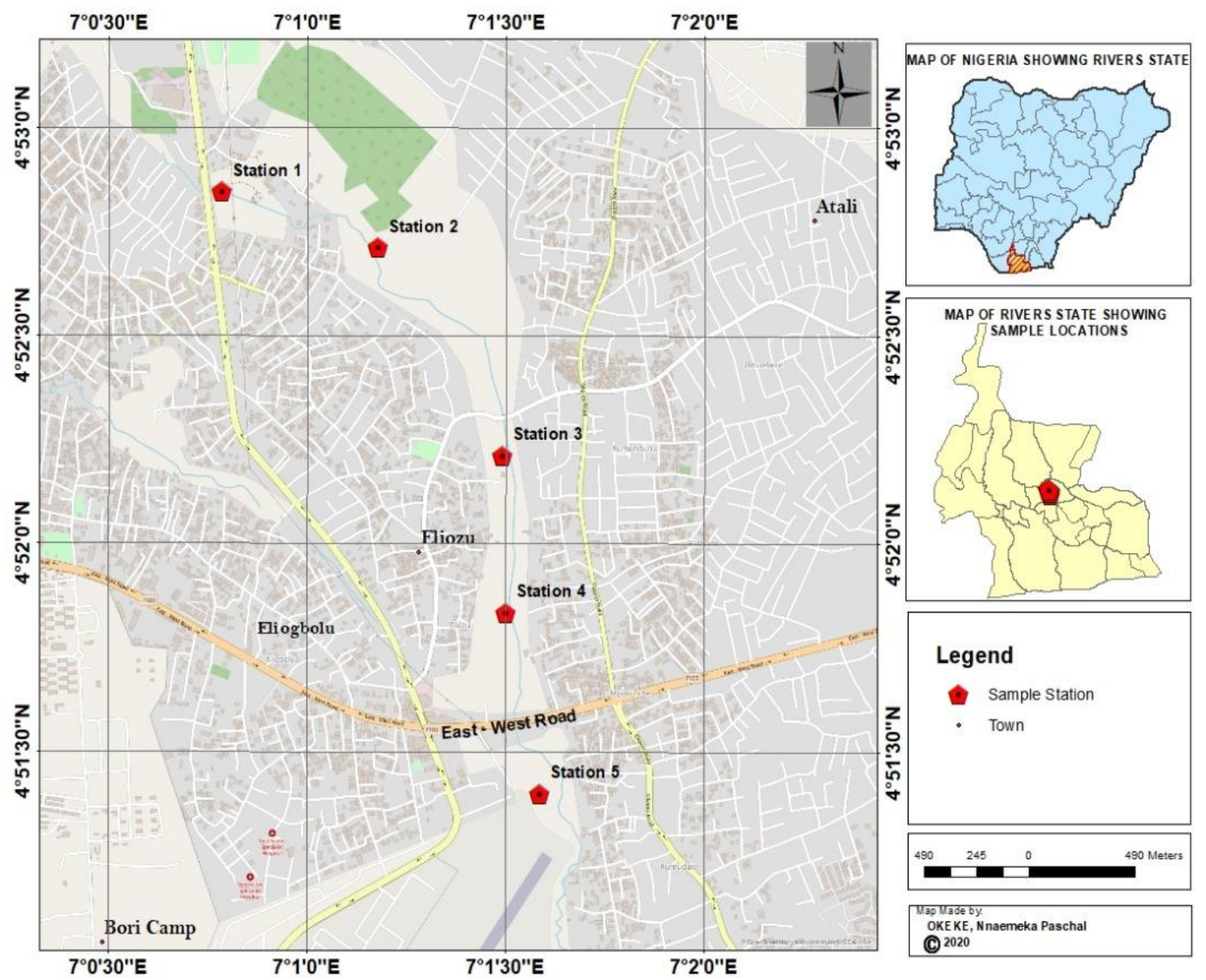

Figure 1: Map of Study Area

\section{MATERIALS AND METHODS Pre-Field Activities}

A reconnaissance survey was carried out, and sampling stations were established using a global positioning system (GPS). Sample containers were obtained, washed, rinsed thoroughly and labeled accordingly. Reagents for analysis were freshly prepared and instruments to be used were properly calibrated.

\section{Sampling and Storage}

In order to evaluate the contamination load on the surface water of the stretch (Mini-Whuo stream), five sampling points were established. Various water samples were collected from each sampling point for a period of six months (MayOctober, 2019). Vials were used to collect water samples for heavy metal analysis and microbial load. Glass bottles were used to collect water samples for both total hydrocarbon content (THC) and heavy metals analysis. Water samples collected were stored in ice-chest and transferred to the institute of pollution studies (IPS) Rivers State University for analysis.

In-situ properties such as temperature, $\mathrm{pH}$, electrical conductivity, total dissolved solids, dissolved oxygen and salinity were measured on field immediately after sampling, using the calibrated Extech Meter. The chemical analyses of the water samples were done using standard laboratory methods as established by the American Public Health Association (APHA) [6]. The suitability of Mini-Whuo stream for domestic and agricultural use was evaluated by comparing the values of water quality 
parameters with those of the WHO drinking water guidelines (2008). The results of all the

analysis are presented on Table 1.

\section{RESULTS AND DISCUSSION}

\section{Table 1: Average Spatial Variation of Physicochemical, Heavy Metals and Microbiological Properties in the Water Samples}

\begin{tabular}{|c|c|c|c|c|c|c|}
\hline Parameter & Station 1 & Station 2 & Station 3 & Station 4 & Station 5 & WHO \\
\hline Temperature ${ }^{0} \mathrm{C}$ & $29.3 \pm 1.9$ & $30.4 \pm 2.0$ & $31 \pm 1.8$ & $30 \pm 1.0$ & $29 \pm 1.0$ & $<40$ \\
\hline $\mathrm{pH}$ & $6.7 \pm 0.3$ & $6.6 \pm 0.2$ & $6.6 \pm 0.3$ & $6.4 \pm 0.0$ & $6.5 \pm 0.2$ & $6.5-8.5$ \\
\hline Dissolved Oxygen (mg/L) & $6.6 \pm 1$ & $5.6 \pm 2.3$ & $4.8 \pm 2.7$ & $4.8 \pm 1.3$ & $5.5 \pm 2.1$ & 7.50 \\
\hline Biochemical Oxygen & $2.8 \pm 0.4$ & $3.8 \pm 0.9$ & $4.1 \pm 1.2$ & $4.4 \pm 1$ & $3.1 \pm 0.3$ & $<40$ \\
\hline \multicolumn{7}{|l|}{ Demand $(\mathrm{mg} / \mathrm{L})$} \\
\hline Salinity (ppt) & $0.01 \pm 0.00$ & $0.01 \pm 0.00$ & $0.01 \pm 0.0$ & $0.01 \pm 0.00$ & $0.01 \pm 0.00$ & - \\
\hline $\begin{array}{l}\text { Electrical Conductivity } \\
(\mu \mathrm{S} / \mathrm{cm})\end{array}$ & $92.5 \pm 12.1$ & $172.8 \pm 142.1$ & $112.3 \pm 59.1$ & $102.05 \pm 22.41$ & $81.53 \pm 20.07$ & 100 \\
\hline $\begin{array}{l}\text { Total Dissolved Solids } \\
(\mathrm{mg} / \mathrm{l})\end{array}$ & $46.2 \pm 6.8$ & $87 \pm 71$ & $56.6 \pm 29.7$ & $50.8 \pm 11$ & $41 \pm 10$ & 50 \\
\hline Turbidity (NTU) & $8.1 \pm 1.6$ & $12.2 \pm 1.6$ & $18.1 \pm 2.8$ & $12.9 \pm 1.7$ & $11.2 \pm 1.8$ & 50 \\
\hline Chloride (mg/L) & $6.6 \pm 2.1$ & $7.8 \pm 0.9$ & $7 \pm 2.3$ & $7.7 \pm 3.1$ & $5.6 \pm 1.6$ & 250 \\
\hline Total Alkalinity (mg/L) & $41.6 \pm 12.8$ & $52.4 \pm 30.3$ & $50.6 \pm 29.7$ & $27.4 \pm 8.1$ & $27.4 \pm 8.6$ & 500 \\
\hline Total Hardness (mg/L) & $32.5 \pm 9.9$ & $63.7 \pm 23.5$ & $40.6 \pm 8.5$ & $23.6 \pm 9.9$ & $31 \pm 15.3$ & 500 \\
\hline Total Hydrocarbon (mg/L) & $0.2 \pm 0.2$ & $0.2 \pm 0.2$ & $1 \pm 1.1$ & $0.5 \pm 0.7$ & $0.0 \pm 0.0$ & $100-300$ \\
\hline Nitrate $(\mathrm{mg} / \mathrm{L})$ & $0.5 \pm 0.2$ & $0.3 \pm 0.1$ & $2.2 \pm 1.1$ & $0.2 \pm 0.1$ & $0.5 \pm 0.2$ & 10 \\
\hline Sulphate $(\mathrm{mg} / \mathrm{L})$ & $2.9 \pm 1.5$ & $3.6 \pm 2.1$ & $6.9 \pm 0.9$ & $6.5 \pm 0.8$ & $6.1 \pm 1.6$ & 250 \\
\hline Phosphate (mg/L) & $0.0 \pm 0.0$ & $0.0 \pm 0.0$ & $0.0 \pm 0.0$ & $0.0 \pm 0.0$ & $0.0 \pm 0.0$ & 5 \\
\hline Magnesium (mg/L) & $5.8 \pm 3.6$ & $10.6 \pm 8.4$ & $15.1 \pm 13.7$ & $14.2 \pm 14.3$ & $7.9 \pm 5$ & 20 \\
\hline Ammonia (mg/L) & $0.0 \pm 0.0$ & $0.5 \pm 0.1$ & $0.0 \pm 0.0$ & $0.6 \pm 0.6$ & $0.0 \pm 0.0$ & 0.30 \\
\hline Iron $(\mathrm{mg} / \mathrm{L})$ & $4.6 \pm 0.8$ & $3.6 \pm 0.6$ & $3.6 \pm 0.5$ & $3 \pm 0.6$ & $3.6 \pm 0.7$ & 0.3 \\
\hline Lead $(\mathrm{mg} / \mathrm{L})$ & BDL & BDL & BDL & BDL & BDL & 0.01 \\
\hline Cadmium (mg/L) & BDL & BDL & BDL & BDL & BDL & 0.01 \\
\hline Chromium (mg/L) & BDL & BDL & BDL & BDL & BDL & 0.05 \\
\hline $\operatorname{Nickel}(\mathrm{mg} / \mathrm{L})$ & BDL & BDL & BDL & BDL & BDL & 0.01 \\
\hline Total Heterotrophic & $2.6 \pm 0.5$ & $3.4 \pm 0.6$ & $6.2 \pm 1.4$ & $5.9 \pm 0.9$ & $6.4 \pm 0.6$ & $0-2$ \\
\hline Bacteria $\left(\mathrm{x} 10^{3} \mathrm{cfu} / \mathrm{MLN}\right)$ & & & & & & \\
\hline $\begin{array}{l}\text { Total Coliform Bacteria } \\
\left(\mathrm{MPN} / 100 \mathrm{ml}^{-1}\right)\end{array}$ & $323.8 \pm 43.9$ & $221.8 \pm 23.2$ & $44.3 \pm 9$ & $321.2 \pm 19.4$ & $270.2 \pm 32.9$ & $<100$ \\
\hline $\begin{array}{l}\text { Faecal Coliform } \\
\text { Bacteria (MPN/100ml) }\end{array}$ & $38 \pm 10.5$ & $4.3 \pm 2.7$ & $20.3 \pm 10.1$ & $4.2 \pm 3.3$ & $59.5 \pm 16.9$ & \\
\hline
\end{tabular}

Temperature levels across all stations in all months of sampling were within the guidelines according to set standards by WHO (2011) for good water quality $10-30{ }^{\circ} \mathrm{C}[38]$.

The water $\mathrm{pH}$ of the water stretch ranged between 6.4 and 6.7 across stations. The highest $\mathrm{pH}$ value was recorded at station 2, as against the lowest value recorded at station 4 . Spatially $\mathrm{pH}$ value decreased downstream, this is due to different wastes such as agricultural, industrial or chemicals discharged at each station. The $\mathrm{pH}$ values indicate that water is neither acidic nor basic [19].

Dissolved Oxygen of water stretch ranged between 4.8-6.8 $\mathrm{mg} / \mathrm{L}$ across stations. The highest dissolved oxygen value was measured at station 1 , and the lowest value at station 3 . Low levels of dissolved oxygen in water could be attributed to discharge of effluents rich in organic matter [21], whereas an increase in dissolved oxygen levels in water could be 
influenced by frequent rainfall as at the time of sampling [22]. Sampling activities were within the period of rainfall, therefore the cause of increased runoffs.

Biochemical oxygen demand value in water varied from 2.4-4.4 mg/L across stations. The highest biochemical oxygen demand value was measured at station 4 as against the lowest values recorded at station 1 .The minimum levels of biochemical oxygen demand could be attributed to a flowing stream that empties itself into it, as well as its self-cleansing nature [23].

Salinity recorded $0.01 \mathrm{ppt}$ across stations. This is an indication that the water is a freshwater system [21].

Electrical conductivity of water ranged between 81.5-172.8 $\mu \mathrm{S} / \mathrm{cm}$ across stations. Maximum value was recorded at station 2 , while the minimum value station 5.Values obtained is indicative of the water being a freshwater system [26].

Total dissolved solid of water recorded were between 41-86.5 mg/l across stations. The highest value measured at station 2 against the lowest value recorded at station 1 . The levels measured could be influenced by municipal and aerosol fallout from surrounding automobile sites around the study area [27].

The mean concentration of turbidity in water ranged between 8.1-18.1 NTU. The highest value recorded at station 3, as against the lowest value recorded at station 1 . These levels were below the set standard of WHO, they are however higher than natural background of 5 NTU. The increased turbidity could be as a result of soil erosion, decay of dead organic matter and some anthropogenic activities [26].

The chloride content of water ranged from 5.6$7.8 \mathrm{mg} / \mathrm{L}$. The maximum value was recorded at station 4, against the lowest value recorded at station 3. High concentration of chloride in the study area could be due to sewage contamination resulting from homes, offices and shops as well as market wastes [27].
Total hardness of water across stations ranged between $23.6-63.7 \mathrm{mg} / \mathrm{L}$. The lowest value was recorded at station 4 , highest value was recorded at station 2 .

Magnesium level in the water samples ranged from 5.8-15.1 $\mathrm{mg} / \mathrm{L}$. The highest value was recorded at station 3, against the lowest value recorded at station 1 . These levels are slightly higher than the recommended value set by WHO 2008 [28].

\section{Nutrients: phosphate, sulphate, nitrate, ammonia.}

Phosphate, sulphate, nitrate and ammonia are essential properties in water, they exist in different inorganic forms in both soil and water. In considerable concentrations, phosphate, sulphate and nitrate contribute to the stability of the particular ecosystem, however when in excess concentration they cause algae bloom and make plants grow excessively thereby resulting in eutrophication. For instance the use of phosphate based detergents has impacted water quality by introducing excess nutrients to the water [17,29]. Values obtained for sulphate, phosphate and nitrate were below permissible limits of WHO 2008, thus does not pose treat to water bodies [30].

Total hydrocarbons are classified as organic compounds that contains only hydrogen and carbon. They are brought into the system via petroleum and biogenic hydrocarbons. They are important environmental pollutants that pose threat to human health particularly marine environment if not handled properly. The values are significantly lower than the recommended values [31-34].

\section{Heavy Metal Levels}

Iron ion levels in water ranged from 3-4.6 mg/L and this levels are higher than the standard permissible limits of water according to the WHO standard. The high levels of iron ion in water could be as a result of numerous human activities involving metal working, corrosion of metals and runoff of steel into the system [35,36]. Comparatively measurement of lead, cadmium, chromium, and nickel concentrations 
across all stations were below detectable limits of $0.01 \mathrm{mg} / \mathrm{L}$. This is traceable to some activities that did not significantly affect the water body [36].

\section{Microbiological Study of Water}

Total heterotrophic, faecal coliform and total coliform bacteria count across stations in months of sampling indicated the presence of bacteria in surface water which may be as a result of municipal wastewater, human and animal excrement as well as runoff from farm land, abattoir and market wastes. This observation is an indication that the water may not be good for consumption [31,37]. According to Iyama and Edori 2014[37], there is a greater risk of water borne diseases such as cholera, hepatitis A, Salmonellosis and Shigellosis water that is contaminated with bacteria. Freshwater is essential for the sustenance of life. Sadly in recent times, water bodies are abused via anthropogenic activities.

\section{Water Quality Index (WQI)}

WQI is defined as a rating that reflects the composite influence of different water quality parameters. Hence, for calculating the WQI in the present study, 25 parameters namely; temperature, $\mathrm{pH}$, electrical conductivity, salinity, total dissolved solids, total hardness, alkalinity, turbidity, total hydrocarbon, ammonia, phosphate, biochemical oxygen demand, dissolved oxygen, magnesium, chloride, sulphate, nitrate, lead, chromium, cadmium, nickel, iron, total heterotrophic bacteria, total coliform bacteria and faecal coliform bacteria have been considered. The weighted arithmetic water quality index was used to determine the water quality index of the water [35]. Thus using the formula WQI $=\sum W i Q i / \sum W i$

The quality rating (Qi) for each parameter is calculated by using the following,

$\begin{array}{lll}\mathrm{Qi} & = & 100((\mathrm{Ve}-\mathrm{Vi} / \mathrm{Vs}-\mathrm{Vi})) \\ \mathrm{Where} & & \\ \mathrm{Ve} & = & \text { experimental value } \\ \mathrm{Vi} & = & \text { idea value } \\ \mathrm{Vs} & = & \text { standard values } \\ \mathrm{Wi} & = & \mathrm{K} / \mathrm{Vs} \\ \mathrm{Wi} & = & \text { unit weight for each parameter } \\ \mathrm{K} & = & \text { Proportionality constant }\end{array}$

The quality rating as per WAWQI

$\begin{array}{ll}\text { Excellent } & <50 \\ \text { Good water } & 50-100 \\ \text { Poor water } & 200-300\end{array}$

Poor water $200-300$
Unsuitable for use 300

The determination of the water quality index of Mini-Whuo stream is shown in Table 2

Table 2: Water quality Index Study of water from Mini-Whuo stream.

\begin{tabular}{llllll}
\hline Parameter & $\mathbf{C i}$ & $\mathbf{S i}$ & $\mathbf{Q i}$ & $\mathbf{W i}$ & $\mathbf{Q i}{ }^{*} \mathbf{W i}$ \\
\hline Temperature ${ }^{\circ} \mathrm{C}$ & 29.8 & 30 & 99.2 & 0.0 & 3.3 \\
Ph & 6.5 & 8.5 & 77 & 0.1 & 9.1 \\
Dissolved Oxygen (mg/L) & 5.5 & 7.5 & 73.3 & 0.1 & 9.8 \\
Biochemical Oxygen Demand $(\mathrm{mg} / \mathrm{L})$ & 3.7 & 39.9 & 9.1 & 0.0 & 0.2 \\
Salinity (ppt) & 0.0 & 0.0 & & & \\
Electrical Conductivity ( $\mu \mathrm{S} / \mathrm{cm})$ & 112.2 & 100 & 112.2 & 0.0 & 1.1 \\
Total Dissolved Solids $(\mathrm{mg} / \mathrm{L})$ & 56.2 & 50 & 112.4 & 0.0 & 2.3 \\
Turbidity (NTU) & 12.5 & 50 & 25 & 0.0 & 0.5 \\
Chloride $(\mathrm{mg} / \mathrm{L})$ & 7 & 25 & 2.8 & 0.0 & 0.0 \\
Total Alkalinity (mg/L) & 39.9 & 500 & 8 & 0.0 & 0.0 \\
Total Hardness (mg/L) & 38.3 & 500 & 7.7 & 0.0 & 0.0 \\
Total Hydrocarbon $(\mathrm{mg} / \mathrm{L})$ & 0.4 & 300 & 0.1 & 0.0 & 0.0 \\
Nitrate $(\mathrm{mg} / \mathrm{L})$ & 0.8 & 10 & 7.5 & 0.1 & 0.8 \\
Sulphate (mg/L) & 5.2 & 250 & 2.1 & 0.0 & 0.0
\end{tabular}




\begin{tabular}{llllll}
\hline Parameter & Ci & Si & Qi & Wi & Qi * Wi \\
\hline Phosphate (mg/L) & 0.0 & 5 & 0.4 & 0.2 & 0.1 \\
Magnesium (mg/L) & 10.7 & 20 & 53.6 & 0.1 & 2.7 \\
Ammonia (mg/L) & 0.3 & 0.3 & 84.8 & 3.3 & 282.6 \\
Iron (mg/L) & 3.7 & 0.0 & 12307.8 & 33.3 & 410259.3 \\
Lead (mg/L) & 0.0 & 0.0 & 10 & 100 & 1000 \\
Cadmium (mg/L) & 0.0 & 0.0 & 10 & 100 & 1000 \\
Chromium (mg/L) & 0.0 & 0.0 & 2 & 20 & 40 \\
Nickel (mg/L) & 0.0 & 0.0 & 10 & 100 & 1000 \\
Total Heterotrophic Bacteria (x103cfu/MLN) & 4.9 & 2 & 244.7 & 0.5 & 122.3 \\
Total Coliform Bacteria (MPN/100ml-1) & 236.3 & 99.9 & 236.5 & 0.0 & 2.4 \\
Faecal Coliform Bacteria (MPN/100ml) & 25.3 & 0.0 & 0.0 & 0.0 & 0.0 \\
& & & & $\sum \mathbf{W i}$ & $=\sum_{\mathbf{4 1 3}} \mathbf{Q i * W i}$ \\
\hline
\end{tabular}

\section{WQI = 1156.01}

Excellent $\quad<50$

Good water $\quad 50-100$

Poor water 200-300

Unsuitable for use 300

$$
\begin{aligned}
& \mathrm{Ci}=\text { concentration } \\
& \mathrm{Si}=\text { standard }
\end{aligned}
$$

\section{CONCLUSION}

Based on this study on Mini-Whuo stream, the water quality parameters such as temperature, $\mathrm{pH}$, electrical conductivity, salinity, total dissolved solids, total hardness, alkalinity, turbidity, total hydrocarbon, ammonia, phosphate, biochemical oxygen demand, dissolved oxygen, magnesium, chloride, sulphate, nitrate, lead, chromium, cadmium, nickel, iron, total heterotrophic bacteria, total coliform bacteria and faecal coliform bacteria

\section{REFERENCES}

[1] A.A. Adeola, C. N. Valerie, L. N. Kelechi and J. Anuoluwapo (2015). Nitrate and Phosphate Pollution in Surface Water of Nwaja Creek, Port Harcourt, Niger Delta, Nigeria. International Journal of Geology, Agriculture and Environmental Science, 3, 2348-2354.

[2] A. Chimezie, E. Teddy and U. Oghenetega (2013). Heavy Metal Levels in Soil Samples from Highly Industralized Lagos Environment. African Journal of evaluated from samples obtained from the MiniWhuo stream showed that the Mini-Whuo stream is contaminated by physicochemical, heavy metal and microbiological parameters. This may be attributed to intense anthropological activities consequently resulting in biodegradable and non-biodegradable pollutants. It is thus necessary to create awareness among people and the society via stringent environmental and essential measures, since inhabitants make use of the water.

Environmental Science and Technology, 7, 917-924.

[3] A.N. Kaizer and S. A. Osakwe (2010). Physicochemical characteristics and Heavy Metal Levels in Water Samples from Five River Systems in Delta State, Nigeria. Journal of Applied Sciences; Environmental Management, 14, 83-87.

[4] A.A. Oluyemi, C. Nkaziobi, A. E Okon, O. Tokunbo, U. U. Sammy and U. H. Edet (2014). Seasonal Variation in the Physicochemical Characteristics of 
Surface Water in Etche River, Niger Delta Area of Nigeria. IOSR Journal of Environmental Science, Toxicology and Food Technology, 8, 1-7.

[5] A.O. Amoo, A. W. Aakari, E. M. Ijanu, A. O. Adeleye and N. B. Amoo (2017). Physiochemical and Bacteriological Assessment of Surface Worker Quality. A Case study of Jakara River, North-Western Nigeria. International Journal of Applied Research and Technology, 6, 65-74.

[6] APHA, American Public Health Association (2005); Standard methods for the examination of water and waste water; $20^{\text {th }}$ edition, Washington.

[7] B.A. Adeleken and K. D. Abegunde (2011). Heavy Metal Contamination of Soil and Groundwater at Automobile Mechanic Villages in Ibandan, Nigeria. International Journal of the Physical Sciences, 6, 1045-1058.

[8] B.O. Dimowo (2013). Assessment of Some Physicochemical Parameters of Rivers Ogun (Abiokuta, Ogun State, South Western Nigeria) in Comparison with national and international standards. International Journal of Aquaculture, 3, 79-84.

[9] E.A. Oluyemi, A. S. Adekunle, A. A. Adenuga, and W. O Makinde (2010). Physiochemical Properties and Heavy Metal Content of Water Sources in Ife North Local Government Area of Osun State Nigeria. African Journal of Environmental Science and Technology, 4, 691-697.

[10] E.C. Kelvin (2015). Water supply management policy in Nigeria: Challenges in the Wetland Area of Niger Delta. European Scientific Journal, 11, 18571865 .

[11] E.D. Imaobong and J. N. Prince (2017). Total Petroleum Hydrocarbon
Concentration in Surface Water of Cross River Estuary, Niger Delta, Nigeria. Asian Journal of Environment an Ecology, 1, 1-7

E.I. Aniefiok, A. H. Thomas, O. O. Clement, R. A. Expedem and J. Iniemem (2018). Petroleum Hydrocarbons Contamination of Surface Water and Ground Water in the Niger Delta Region of Nigeria. Journal of Environmental Pollution and Human Health, 6, 5061.

[13] I.F. Vincent-Akpu and L. O. Yanadi (2014). Levels of Lead, Iron and cadmium Contamination in Fish, Water and Sediment from Iwofe Site on New Calabar River, Rivers State. International Journal of Extensive Research, 3, 10-15.

[14] G. Hidenori (2006). Origin of Earth's Oceans: An assessment of the total amount, history and supply of water. Geochemical Journal, 50, 27-42.

[15] H.O. Nwankwoala and O.V.A. Ogbonna (2017). Water quality surveillance of boreholes around landfills sites in Eliogbolo-Eliozu, Obio/Akpor Local Government Area, Rivers State, Nigeria Environmental Risk Assess Remediation, 1, 44-49.

[16] I.A. Ademiluyi and J.A. Odugbesan, (2008). Sustainability and impact of community water supply and sanitation programmes in Nigeria. African Journal of Agricultural Research, 3, 811-817.

[17] I.L. Dapam, E. G. Ibrahim and J. N. Egila (2016). Assessment of Physicochemical Parameters and Heavy Metal Spaciation Study of Water and Bottom Sediments from River Jibam in Chip District of Pankshin Local Government Area, Plateau State Nigeria. Journal of Applied Chemistry, (IOSR-JAC), 9, 57-64.

[18] I. Owhonda, C. Ekpendu, O. Mmedorenyin. I. Okoroafor, C. Obunwo 
and M. Chinedu (2018). Effect of Urban Effluent on River Water Quality in the Niger Delta. Frontiers in Environmental Microbiology, 4, 110114.

[19] J.F.N. Abowei (2010). Salinity, Dissolved Oxygen, $\mathrm{pH}$ and Surface Water Temperature Conditions in Nkoro River, Niger Delta, Nigeria. Advance Journal of food science and Technology, 2, 36-40.

[20] M.A. Hossain, M. F. Hossain, A. N. M Fakruddin and S. I Hhan (2016). Removal of Ammonia-N Pollution from Surface Water by Sustainable Environmental Techniques. Journal of Ecologic and Environmental Sciences, 4, 1-11.

[21] M.D Wogu and A. Okaka (2011). Pollution Studies on Nigerian Rivers: Heavy Metals in Surface Water of Warri River, Delta State. Journal of Biodiversity and Environmental Sciences, 1, 7-12.

[22] M.K. Olatunji, T. A. Kolawole, B. O. Albert and I. O. Anthony (2011). Assessment of Worker Quality in Asa River (Nigeria) and its Indigenous ClaraisGariepinus

Fish. International Journal of Environmental Research and Public Health, 8, 4332-4352.

[23] M. Moslen and A. Aigberua (2018). Heavy Metals and Hydrocarbon Contamination of Surface Water in Azuabie Creek within Bonny Estuary, Nigeria. Journal of Applied Science and Environmental Management, 22, 10831088.

[24] N.E. Joshua, O. O. John, E. P. Oluwaseun and A. M. M Titus (2016). Assessment of Trace Metals Contamination of Surface Water and Sediment. A Case Study of Mrudi River, South Africa, www.mdpi.com/journal/ sustainability, 8, $135-147$
[25] N.C. Shalom, C. N Obinna, Y. Adebayo, and V. N. E Oluwadamisi (2011). Assessment of Water Quality in Cannanland, Ota, Southwest Nigeria. Agricultural and Biology Journal of North America, 2, 577-583.

[26] O. D.Opaluwa, M. O. Aremu, L.O. Ogbo, K. A. Abiola, E. Odiba, M. M. Abubakar and N. D Nweze (2012). Heavy Metal Concentration in Soils, Plant Leaves and Crops Grown Around Dump Sites in LafiaMehopolis, Nasarawa State, Mogeroa. Advances in Applied Science Researches, 392, 780-784.

[27] A.O. Numbere (2017). Concentration of Iron and other Physic-chemical Parameters in Ground and Surface Water in Some Mangrove Forest Areas in the Niger Delta, Nigeria. African Journal of Applied Zoology and Environmental Biology, 9, 112.

[28] O.O. Aboyeji (2013). Freshwater pollution in some Nigerian Local Communities, causes, consequences and probable solutions. Academic Journal of Interdisciplinary Studies, 2, 111-117

O. Olayiwola and F. Olubunmi (2016). The Use of Water Quality Index Method to Determine the Potability of Surface Water and Groundwater in the Vicinity of Municipal solid waste Dumpsite in Nigeria. American Journal of Engineering Research, 5, 96-101.

[30] A. Obioma, A. T. Chikanka and N. W. Loveth (2017). Evaluation of Bacteriological Quality of Surface, Well, Bore-hole Area of Rivers State, Niger Delta. Annual Clinic Laboratory Resource, .5, 183-190.

[31] P.J. Puri, M. K. N Yenkie, D. B. Rana and S. U Meshram (2015). Application of water quality index (WQI) for the assessment of surface water quality (Ambazari Lake), European Journal of Experimental Biology, 5, 37-52. 
[32] R.K. Brown. N. I McClelland, R. A Deininger and R. G. Tozer. (1970). Water Quality Index - do we care? Water Sewage Works, 117, 339-343.

[33] R.K. Horton (1965). An Index Number System for Rating Water Quality.Journal of Water Pollution Fed., 37, 300 - 305.

[34] S.E. Inyang, A. B. Aliyu, and A. O. Oyewale (2018). Total Petroleum Hydrocarbon Content in Surface Worker and Sediment of Qua-iboe, River, Ibino, Akwa-Ibom State, Nigeria. Journal of Applied Science and Environmental Management, 22, 1953-1959.

[35] T. Shweta. S. Bhavtosh, S. Prashant and D. Rajendra (2013). Water Quality Assessment in Terms of Water Quality
Index. American Journal of Water Resources, 1, 34-38.

[36] U. Olu, A. P. Ugbomeh, K. N. O. BobManuel and I. Ekweozor (2019). Levels of Selected Heavy Metals in Water and Sediment of Soku Oil Field Area of the Niger Delta, Nigeria. Journal of Aquatic Pollution and Toxicology, 3, 25-30.

[37] W. A. Iyama and O. S. Edori (2014). Analysis of the Water Quality of Imonite Creek in Ndoni, Rivers State, Nigeria. IOSR Journal of Applied Chemistry 7, 6-9

[38] World Health Organization. (2011). Guidelines for Drinking Water Quality $4^{\text {th }}$ Edition. 